\begin{tabular}{l|l} 
Implementasi Pendistribusian Wakaf .... & 49
\end{tabular}

\title{
Implementasi Pendistribusian Wakaf Tunai Sebagai Penunjang Usaha Kecil Menengah di Badan Wakaf Uang \& Badan Wakaf Tunai MUI Yogyakarta
}

\author{
Mulyono Jamal*, Jarman Arroisi**, Nia Puji \\ Agustin $^{* * *} \&$ Khurun'in Zahro' ${ }^{* * * *}$ \\ Universitas Darussalam (UNIDA) Gontor \\ Email: khuruninzahro@unida.gontor.ac.id
}

\begin{abstract}
The number of poor people in Indonesia has continued to increase since the economic crisis in 1997 to the present. Population growth below the poverty line is not due to the problem of natural wealth that is not balanced with the population, but is caused by problems of income distribution and unfair economic access. Optimization of Islamic financial resources can be applied to reduce poverty levels. The distribution of cash waqf funds has an important role as one of the capital in developing the economy. Cash Waqf is also able to have a good impact on poverty alleviation. This study aims to determine the implementation of the distribution of cash waqfas supporting the improvement of Small and Medium Enterprises (SMEs). This study uses qualitative methods by using a field survey research design. The results of this study conclude that the implementation of the distribution of good and directed cash waqf can increase mauquf alaihi income and can support the development of SMEs so that it is more productive.
\end{abstract}

Keywords: Cash Waqf, Business Capital, Small and Medium Enterprises (SMEs).

\footnotetext{
* Dosen Fakultas Syariah Universitas Darussalam (UNIDA) Gontor.

** Dosen Fakultas Ushuluddin Universitas Darussalam (UNIDA) Gontor.

*** Mahasiswa Fakultas Syariah Universitas Darussalam (UNIDA) Gontor.

Dosen Fakultas Syariah Universitas Darussalam (UNIDA) Gontor.
} 


\begin{abstract}
Abstrak
Jumlah penduduk miskin di Indonesia terus bertambah sejak krisis ekonomi pada tahun 1997 hingg saat ini. Pertumbuhan penduduk di bawah garis kemiskinan bukanlah karena persoalan kekayaan alam yang tidak seimbang dengan jumlah penduduk,akan tetapi disebabkan oleh persoalan pendistribusian pendapatan dan akses ekonomi yang tidak adil. Optimalisasi sumber keuangan Islam dapat diterapkan untuk mengurangi tingkat kemiskinan. Pendistribusian dana wakaf tunai memiliki peranan penting sebagai salah satu modal dalam mengembangkan perekonomian. Wakaf tunai juga mampu memberikan dampak baik dalam pengentasan kemiskinan. Penelitian ini bertujuan untuk mengetahui implementasi pendistribusian wakaf tunai sebagai penunjang peningkatan Usaha Kecil Menengah (UKM). Penelitian ini menggunakan metode kualitatif dengan mengggunakan desain penelitian survey lapangan. Hasil penelitian ini menyimpulkan bahwa implementasi pendistribusian wakaf tunai yang baik dan terarah dapat meningkatkan pendapatan mauquf alaihi dan dapat menunjang pengembangan UKM sehingga lebih produktif lagi.
\end{abstract}

Kata Kunci: Wakaf Tunai, Modal Usaha, Usaha Kecil Menengah (UKM).

\title{
Pendahuluan
}

ejak terjadinya krisis multi dimensi dalam kehidupan
(2) masyarakat Indonesia, peranan wakaf menjadi semakin
penting sebagai satu instrumen untuk meningkatkan kesejahteraan masyarakat. ${ }^{1}$ Pesatnya perkembangan zaman, wakaf tidak lagi hanya diasosiasikan pada obyek wakaf berupa tanah, akan tetapi sudah merambah kepada wakaf bentuk lain seperti benda bergerak berupa uang (wakaf tunai). Berdasarkan Keputusan Komisi Fatwa Majlis Ulama Indonesia (MUI) tentang Wakaf Uang pada tanggal 28 Shafar 1423 H/ 11 Mei 2002 bahwa wakaf tunai atau wakaf uang hukumnya jawaz (boleh). ${ }^{2}$

${ }^{1}$ M. Apriadi, Efektivitas Penghimpunan dan Pengelolaan Wakaf Uang pada Baitu Maal Muamalat (BMM), (UIN Syarif Hidayatullah, 2010), p. 1.

${ }^{2}$ S. Hairunas, Manajemen Pendistribusian Wakaf Tunai di Badan Wakaf Uang Tunai Majelis Ulama Indonesia Daerah Istimewa Yogyakarta. 
Implementasi Pendistribusian Wakaf .... 51

Secara umum wakaf tunai adalah penyerahan aset wakaf berupa uang tunai yang tidak dapat dipindahtangangkan dan dibekukan untuk selain kepentingan umum yang tidak mengurangi ataupun menghilangkan jumlah pokoknya. ${ }^{3}$

Kesejahteraan merupakan tujuan hidup masyarakat berbangsa dan bernegara, pertumbuhan ekonomi dan pemerataan pendapat menjadi kunci atas tercapainya kesejahteraan tersebut. Di tengah problem sosial masyarakat Indonesia dan tuntutan akan kesejahteraan ekonomi akhir-akhir ini, keberadaan wakaf sangat diperlukan.

Wakaf memiliki dua dimensi antara teologis dan sosial. Wakaf menurut Azizy merupakan salah satu bentuk ibadah, yang nilainya lebih dominan pada ibadah sosial. Ini berarti juga merupakan salah satu jenis dari beberapa jenis ibadah serupa, seperti amal baik, sedekah dan infaq yang kesemuanya merupakan bentuk charity (charity table endowment). ${ }^{4} \mathrm{Di}$ Indonesia wakaf tunai mulai diperkenalkan dan dikembangkan setelah A. Mannan memberikan seminar di Indonesia tentang wakaf tunai pada tahun 2001. Wakaf di Indonesia dalam pengelolaannya mengalami perubahan dan perkembangan signifikan setelah pada tahun 2004 lahirnya Undang-Undang No. 41 tahun 2004 tentang Wakaf dan merupakan satu kemajuan yang sangat signifikan bagi umat Islam. Setelah diresmikan UU No. 41 tahun 2004 tersebut, kemudian diteruskan dengan dibentuknya Badan Wakaf Indonesia (BWI) sebagai lembaga independen yang secara khusus mengelola dana waqaf dan beroperasi secara nasional. Tugas dari lembaga adalah untuk

Universitas Islam Negeri Sunan Kalijaga Yogyakarta, 2017, p. 3.

${ }^{3}$ A. Syafiq, "Wakaf Tunai untuk Pemberdayaan Usaha Kecil”, Jurnal ZISWAF, Vol. 1, 2014, p. 409.

${ }^{4}$ S. Fatimah, "Implementasi Wakaf Tunai Dalam UU No 41 Tahun 2004 di Bank Muamalat Indonesia Lampung Timur", Jurnal As-Salam, Vol. 4, 2015, p. 19. 
52 Mulyono Jamal, Jarman Arroisi, Nia Puji Agustin \& Khurun'in Zahro'

memajukan dan mengembangkan perwaqafan nasional di Indonesia. $^{5}$

Wakaf memiliki potensi yang sangat prospektif untuk meningkatkan kesejahteraan umat, terutama konsep wakaf uang atau wakaf tunai. Lahirnya UU No. 41 tahun 2004 diarahkan untuk memberdayakan wakaf yang merupakan salah satu instrumen dalam membangun kehidupan sosial ekonomi umat Islam. ${ }^{6}$

Pendayagunaan dan pengembangan wakaf baik aset bergerak maupun aset tidak bergerak yang ada di Indonesia membutuhkan komitmen bersama antara pemerintah, ulama dan masyarakat serta komponen lainnya yang relevan. Dan perlu dirumuskan kembali mengenai berbagai hal seperti harta yang diwakafkan, peruntukan wakaf dan nadzir serta pengelolaan wakaf secara produktif professional. ${ }^{7}$

BWI melakukan gerakan wakaf uang, dan melibatkan LKS sebagai mitra kerja BWI. Dalam pengelolaannya wakaf uang dikelola oleh nadzir dalam hal ini adalah Bank Syariah yang secara resmi telah ditetapkan oleh Menteri sebagai Lembaga Keuangan Syariah Penerima Wakaf Uang (LKS-PWU). Dalam menggalang wakaf uang, LKS dipilih sebagai mitra karena mempunyai beberapa kelebihan. Pertama, jaringan kantor yang membantu nadzir menghimpun wakaf uang. Luas jaringan mampu menjangkau hampir seluruh wilayah Indonesia. Kedua, jaringan delivery channel. Jaringan ini meliputi ATM, EDC, phone banking, mobile banking dan internet bangking. Efektivitas dan efesiensi jaringan ini patut dibanggakan. Banyak orang

5 Hazami, "Peran dan Implemntasi Waqaf dalam Peningkatan Kesejahteraan Masyarakat”, Jurnal Penelitian Sosial Keagamaan, Vol. 10, 2016, p. 240.

${ }^{6}$ H. Setyadi, Pengelolaan Pengembangan Wakaf Uang Berdasarkan Peraturan Pemerintah No. 42 Tahun 2006 Pasal 48 pada Bank BPD DIY Syariah, Jurnal Ekonomi Syariah, Vol. 2, 2017, p. 53.

7 Hazami, "Peran dan Implemntasi Waqaf dalam Peningkatan Kesejahteraan Masyarakat", p. 241. 
Implementasi Pendistribusian Wakaf .... 53

berbondong-bondong mengunduh manfaat dan kemudahan dari kemajuan teknologi. Ketiga, jaringan mitra atau aliansi. LKS telah berjejaring dengan berbagai mitra terkait. Melalui jaringan itu, LKS bisa memasuki kawasan Nusantara. Pengalaman LKS dalam bermitra menjadi faktor yang akan selalu dipertimbangkan dalam mengoptimalkan penghimpunan wakaf. ${ }^{8}$

Tepatnya di kota Yogyakarta ada sebuah badan wakaf tunai bentukan dari MUI Provindi D.I. Yogyakarta yang bernama Badan Wakaf Uang/ Tunai MUI dan mereka bekerjasam dengan Bank BPD Syariah Yogyakarta sebagai LKSPWU dalam pelayanan penerimaan wakaf uang/ tunai di Yogyakarta. Bank BPD DIY Syariah merupakan LKS-PWU yang resmi ditunjuk oleh pemerintah dan satu- satunya LKS-PWU di Yogyakarta yang resmi di tunjuk oleh pemerintah pusat. Pendayagunaan dana wakaf uang/ tunai adalah program nadzir dalam pemanfaatan uang wakaf yang sudah terkumpul dari para wakif yang nantinya akan disalurkan kepada penerima manfaat wakaf mauquf alaihi. ${ }^{9}$

Penerapan wakaf uang sebagai salah satu bentuk wakaf produktif pada masa sekarang akan mempunyai keunggulan yang lebih besar dari wakaf tradisional, yaitu benda bergerak atau benda tidak bergerak. Identik di masyarakat apabila dikatakan harta wakaf, maka langsung dihubungkan dengan sekolah, rumah sakit atau kuburan. Secara umum, wakaf benda bergerak atau tidak bergerak hanya dapat dilakukan oleh orang yang memiliki harta lebih. Hal inilah yang menyebabkan kekayaan wakaf di Indonesia masih sedikit. Selain karena jumlah harta wakaf yang masih sedikit, pengelolaannya pun

${ }^{8} \mathrm{H}$, Setyadi, "Pengelolaan Pengembangan Wakaf Uang Berdasarkan Peraturan Pemerintah No. 42 Tahun 2006 Pasal 48 Pada Bank BPD DIY Syariah", Jurnal Ekonomi Syariah, 2, 2017, p. 54.

${ }^{9}$ M. U. Efendi, Studi Pendayagunaan Dana Wakaf Tunai pada Badan Wakaf Uang Tunai MUI Provinsi D.I. Yogyakarta, 2014, p. 7. 
54 Mulyono Jamal, Jarman Arroisi, Nia Puji Agustin \& Khurun'in Zahro'

masih belum menerapkan manajemen modern. Sedangkan wakaf uang dapat dilakukan banyak orang meskipun tidak kaya. Seseorang dapat berwakaf uang sebesar Rp. 100.000,00. Wakaf uang dihimpun dalam sebuah wadah, sehingga modal usaha yang besar. Dana wakaf yang terkumpul dapat dikelola secara produktif dengan lembaga pengelolah yang memiliki kopetensi dan kapabilitas serta mampu bekerja secara professional. ${ }^{10}$

\section{Kerangka Teori}

Wakaf berasal dari Bahasa Arab waqaf, yaitu masdar dari kata kerja waqofa, ia mempunyai berbagai makna dan tujuan dan penggunaan ayat itu sendiri. Dari segi bahasa waqf memberi makna berhenti (السكن), mencegah (المنع), dan menahan (المبس)).

Ulama fiqh sepakat makna wakaf mengikuti istilah Bahasa dengan al-habs yang artinya menahan. Ulama Hanafiyah merumuskan definisi wakaf dengan: "Menahan benda milik orang yang berwakaf dan menyedekahkan manfaatnya untuk kebaikan baik untuk sekarang atau masa yang akan datang". Berdasarkan definisi Abu Hanifah, bahwa akad wakaf bersifat ghair lazim (tidak mengikat) dalam pengertian orang yang berwakaf (wakif) dapat saja menarik kembali wakafnya dan menjualnya. ${ }^{11}$

Menurut Ulama Malikiyah wakaf adalah: "Wakaf adalah waqif yang menjadikan manfaat harta yang dimiliki walaupun berupa sewa ataupun hasilnya sepertidirham dengna sighat tertentu dalam jangka waktu tertentu sesuai dengan kehendak waqif". Hampir senada dengan pendapat Abu Hanifah di atas, akad wakaf pun menurut Malikiyah tidak melepaskan hak kepemilikan wakif dari harta yang diwakafkannya. ${ }^{12}$

${ }^{10}$ M. N. Rianto, "Wakaf Uang dan Pengaruhnya terhadap Program Pengentasan Kemiskinan di Indonesia", Jurnal INDO, Vol. 2, 2012, p. 18.

${ }^{11}$ Rozalinda, Manajemen Wakaf Produktif, 2015, p. 14.

${ }^{12}$ Rozalinda, Manajemen Wakaf Produktif, p. 15. 
Implementasi Pendistribusian Wakaf .... 55

Mayoritas Ulama Syafi'i mendefinisikan wakaf dengan: "Menahan harta yang dimanfaatkan dengan tetapnya zat benda yang menghalangi waqif dan lainnya dari tindakan hokum yang dibolehkan atau tindakan hokum yang bertujuan untuk kebaikan dan mendekatkan diri kepada Allah ta'ala". Menurut mayoritas ulama ini, harta yang sudah diwakafkan tidak lagi menjadi milik wakif dan berpindah menjadi milik Allah yang digunakan untuk kebaikan umat Islam. $^{13}$

Ahmad bin Hanbal menyatakan hal yang sama, wakaf tidaklah bersifat lazim kecuali wakif melepaskan hak kepemilikannya dari kekuasaannya dan menyerahkan kepada orang lain, wakif tidak menarik kembali harta wakafnya. ${ }^{14}$ Menurut UU No. 41 tahun 2004 tentang Wakaf, pasal 11, wakaf tunai atau wakaf uang merupakan salah satu wakaf benda bergerak yang dispesifikasi berupa uang. Wakaf tunai adalah wakaf yang dilakukan seseorang, kelompok orang, lembaga atau badan hukum dalam bentuk uang tunai. Termasuk dalam pengertian uang adalah surat berharga. Wakaf tunai merupakan bentuk wakaf produktif dengan mekanisme investasi dana wakaf dan menyalurkan hasil dari pokok modal yang diinvestasikan. Membandingkan dengan wakaf tanah misalnya, wakaf tanah hanya dinikmati oleh masyarakat yang berdomisili disekitar harta wakaf tersebut berada. Sementara masyarakat miskin berdomisili di berbagai tempat, sehingga dibutuhkan sumber pendanaan baru yang tidak terikat tempat dan waktu. Sebab uang bersifat fleksibel dan tidak mengenal batas wilayah pendistribusian. ${ }^{15}$

Menurut para Ulama Fiqh, terutama Imam Syafi'i, Imam Maliki dan Imam Ahmad bin Hambal, wakaf merupakan suatu

\footnotetext{
${ }^{13}$ Ibid, p. 15.

${ }^{14}$ Ibid, p. 16.

15 N. L. Yulma, "Peran Pemberdayaan Wakaf Tunai (Studi Kasus pada BMT Amanah Ummah Surabaya)", Jurnal Ekonomi Syariah Teori Dan
} Terapan, Vol. 3, 2016, p. 860. 
56 Mulyono Jamal, Jarman Arroisi, Nia Puji Agustin \& Khurun'in Zahro'

ibadah yang disyariatkan. Dalam Al-Qur'an terdapat ayat- ayat tentang wakaf, meskipun secara tegas tidak terkait langsung dengan wakaf seperti firman Allah SWT. dalam QS. Ali Imran ayat 92 :

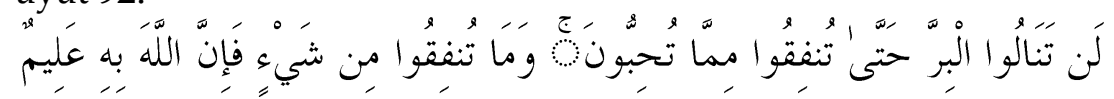

Artinya: Kamu sekali-kali tidak sampai kepada kebajikan (yang sempurna), sebelum kamu menafkahkan sehahagian harta yang kamu cintai. dan apa saja yang kamu nafkahkan Maka Sesungguhnya Allah mengetahuinya.

Sedangkan dalam hadits terdapat beberapa perkataan Nabi SAW, yang bisa dijadikan sebagai pedoman, diantaranya:

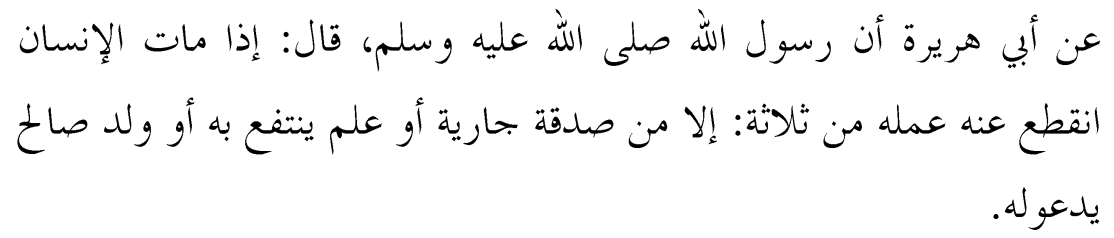

Dari Abu Hurairah, sesungguhnya Rasululah SAW, bersabda: apabila anak Adam (manusia) meninggal duna maka putuslah amalnya, kecuali tiga perkara: shadaqah jariyah. Ilmu yang bermanfaat dan anak shalih yang mendoakan orang tuanya. (HR. Muslim)

Secara historis, wakaf telah ada sejak zaman Rasulullah SAW, meskipun para ulama berbeda pendapat dalam menentukan wakaf pertama dalam Islam. Misalnya Rasulullah pada tahun ketiga hijriyah pernah mewakafkan tujuh kebun kurma di Madinah, Umar mewasiatkan hasil dari pengelola sebidang tanah di Khaibar, Abu Thalhah mewakfkan kebun kesayangannya (kebun buhaira), Abu Bakar mewakafkan sebidang tanahnya di Makkah diperuntukkan kepada anak turunanya yang dating ke Makkah, Utsman bin Afwan mewakafkan hartanya di khaibar. Ali bin Abi Thalib mewakafkan rumahhnya yang popular dengan sebutan Darul Anshar. ${ }^{16}$

${ }^{16}$ A. Atabik, "Manajemen Pengelolaan Wakaf Tunai di Indonesia", 
\begin{tabular}{l|l} 
Implementasi Pendistribusian Wakaf .... & 57
\end{tabular}

Upaya pengembangan wakaf tunai di Indonesia secara lebih maksimal paling tidak terinspirasi oleh dua hal yang mendasar. Pertama, keberhasilan negara-negara Muslim di Timur Tengah seperti Turki, Mesir, Arab Saudi, Yordania dan Qatar dalam mewujudkan kemanfaatan wakaf untuk kepentingan masyarakat. Kedua, kondisi ekonomi masyarakat Indonesia yang semakin terpuruk, sementara kegiatan pengelolaan wakaf yang memiliki nilai ekonomi belum dioptimalkan. ${ }^{17}$

Sejak itu pula mulai berkembang pemikiran dan karya tulis yang mengfokuskan diri pada kajian tentang wakaf uang, khususnya yang berhubungan dengan potensi yang dimiliki bagi upaya pemberdayaan masyarakat.

Dalam Peraturan BWI No. 01 tahun 2009 tentang Pedoman Pengelolaan dan Pengembangan Harta Benda Wakaf yang telah mewakafkan uangnya paling sedikit Rp. 1.000.000 dengan menyertakan asal-usul dan identitas lengkap wakifnya.

Jika wakaf uang dapat diimplementasikan, maka akan terdapat dana potensial yang dapat dipergunakan bagi kemaslahatan umat. Berdasarkan asumsi Cholil Nafis, jika 20 juta umat Islam Indonesia mau mengumpulkan wakaf uang senilai Rp 100 ribu setiap bulan, maka dana yang terkumpul berjumlah Rp 24 triliun setiap tahun. Jika 50 juta orang yang berwakaf, maka setiap tahun akan terkumpul dana wakaf sebesar Rp. 60 triliun. Jika terdapat 1 juta Muslim yang mewakafkan dananya sebesar Rp 100.000 per bulan, maka akan diperoleh pengumpulan dana wakaf sebesar 100 milyar setiap bulannya (Rp. 1,2 triliun pertahun). ${ }^{18}$

ZISWAF, Vol. 1, 2014, p. 89.

17 M. E. Nasution, "Implementasi Wakaf di Indonesia", Paper Dipresentasikan Dalam Acara Seminar Internasional: Perkembangan Dan Kebijakan Wakaf Di Kampus UHAMKA Jakarta, 2017.

Vol. 2, 2009.

${ }^{18}$ C. Nafis, "Wakaf Uang untuk Jaminan Sosial", Jurnal Al-Awqaf, 
58 Mulyono Jamal, Jarman Arroisi, Nia Puji Agustin \& Khurun'in Zahro'

Menurut Mustafa Edwin Nasution tentang potensi wakaf di Indonesia dengan jumlah umat Muslim yang dermawan diperkirakan sebesar 10 juta jiwa dengan rata-rata penghasilan Rp. 500.000 hingga Rp 10.000.000,19 maka paling tidak akan terkumpul dana sekitar 3 triliun pertahun dari dana wakaf seperti perhitungan tabel berikut:

Tabel 1. Potensi Wakaf Uang di Indonesia

\begin{tabular}{|c|c|l|c|c|}
\hline $\begin{array}{c}\text { Tingkat } \\
\text { penghasilan/ } \\
\text { bulan }\end{array}$ & $\begin{array}{c}\text { Jumlah } \\
\text { Muslim }\end{array}$ & $\begin{array}{c}\text { Besar } \\
\text { wakaf/bulan }\end{array}$ & $\begin{array}{c}\text { Potensi wakaf } \\
\text { uang/ bulan }\end{array}$ & $\begin{array}{c}\text { Potensi } \\
\text { wakaf } \\
\text { uang/ } \\
\text { tahun }\end{array}$ \\
\hline Rp 500.000 & 4 juta & $\operatorname{Rp~5000}$ & Rp 20 milyar & $\begin{array}{c}\text { Rp 240 } \\
\text { milyar }\end{array}$ \\
\hline $\begin{array}{c}\text { Rp 1 juta-2 } \\
\text { juta }\end{array}$ & 3 juta & $\operatorname{Rp~10.000}$ & $\operatorname{Rp~30~milyar~}$ & $\begin{array}{c}\text { Rp 360 } \\
\text { milyar }\end{array}$ \\
\hline $\begin{array}{c}\text { Rp 2 juta -5 } \\
\text { juta }\end{array}$ & 2 juta & $\operatorname{Rp~50.000}$ & Rp 100milyar & $\begin{array}{c}\text { Rp 1,2 } \\
\text { triliun }\end{array}$ \\
\hline$>$ Rp 5 juta & 1 juta & $\operatorname{Rp~100.000~}$ & Rp 100 milyar & $\begin{array}{c}\text { Rp 1,2 } \\
\text { triliun }\end{array}$ \\
\hline & & & TOTAL & $\begin{array}{c}\text { Rp 3 } \\
\text { triliun }\end{array}$ \\
\hline
\end{tabular}

Distribusi merupakan faktor yang tidak dapat dipisahkan dari sistem ekonomi, karena dengan distribusi yang baik dapat tercipta keadilan sosial dalam bidang ekonomi dari proses distribusi inilah semua kebutuhan masyarakat dapat terpenuhi, akan tetapi pada proses ini pula banyak terjadi penyalahgunaan wewenang dan sebagainya sehingga faktor ekonomi tersebut tidak merata atau tetap sasaran.

Fungsi distribusi dilakukan oleh badan usaha atau perorangan sejak pengumpulan barang dengan jalan

\footnotetext{
${ }^{19}$ Hasanah, Wakaf Tunai Inovasi Finansial Islam, 2016, p. 43-44.
} 
\begin{tabular}{l|l} 
Implementasi Pendistribusian Wakaf .... & 59
\end{tabular}

membelinya dari produsen untuk disalurkan kepada konsumen. Dana wakaf harus didistribusikan tentunya dengan mengikuti petunjuk dari Allah SWT. Karena harta itu diciptakan Allah yaitu untuk menunjang manusia. Petunjuk dari Allah SWT tentang pendistribusian dan pemanfaatan harta menurut Ghozali sebagai berikut: ${ }^{20}$

1. Harta digunakan untuk kepentingan kebutuhan hidup sendiri. Penggunaan harta untuk kebutuhan hidup dinyatakan oleh Allah SWT dalam surat Al-Mursalat ayat 43:

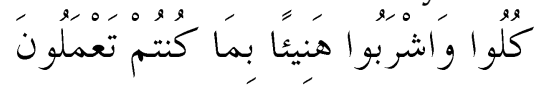

Artinya: (Dikatakan kepada mereka): "Makan dan minumlah kamu dengan enak karena apa yang telah kamu kerjakan".

2. Harta digunakan untuk memenuhi kewajiban kepada Allah SWT. Kewajiban kepada Allah itu ada dua macam, yang pertama adalah kewajiban materi yang berkenaan dengan kewajiban agama yang merupakan hutang kepada Allah, seperti membayar zakat, infaq atau sedekah dan wakaf tunai. Kedua, kewajiban materi yang harus ditunaikan untuk keluarga.

Dalam pemdistribusian hasil wakaf, seorang nadzir wakaf bisa merujuk pada alasan untuk mendatangkan kemaslahatan dan menolak kerusakan. Kemaslahatan disebut oleh asy-Syatibi (730-790 H) sebagai dharuriyat (mendesak), baik untuk agama, nyawa, kebebasan berpikir, reproduksi dan hakhak ekonomi. Menurutnya, kemaslahatan merupakan inti syari'ah Islam. Seluruh hukum Islam sesungguhnya adalah untuk kemaslahatan manusia. ${ }^{21}$

Masyarakat Indonesia selama ini memiliki pemahaman bahwa penyaluran harta benda wakaf hanya untuk keperluan

${ }^{20}$ A. R. Ghazaly, Fiqh Muamalat, Cet. 1, Kencana, 2010, p. 27.

21 As-Syathibi, (n.d.). Al-Muwafaqat fii Ushul As-Syariah (Juz. 1). (Beirut: Dar al-Hadits al-Kutub al-Ilmiyah), p. 7. 
$60 \mid$ Mulyono Jamal, Jarman Arroisi, Nia Puji Agustin \& Khurun'in Zahro'

ibadah saja, seperti pembangunan masjid, pondok pesantren dan keperluan ibadah lain. Pemahaman seperti itu harus ditinggalkan karena nyatanya wakaf dapat dimanfaatkan untuk kepentingan sosial yang lebih luas dan menyeluruh, seperti bidang pendidikan, kesehatan, pelayanan sosial, dan pengembangan ekonomi melalui pemberdayaan usaha kecil dan menengah. Berikut ini diuraikan secara singkat beberapa bidang yang dapat merasakan kesejahteraan yang diinginkan dari pemnfaatan wakaf:

1. Bidang Pendidikan

Pengembangan dalam bidang pendidikan dapat berupa pembangunan pesantren, madrasah perguruan tinggi Islam, lembaga riset untuk masyarakat dan perpustakaan dan pengenmbangan kurikulum, sumber daya manusia, dan proyek-proyek riset teknologi tepat guna.

2. Bidang Kesehatan

Kendala yang dihadapi masyarakat yang kurang mampu salah satunya adalah sulitnya mendapatkan penangan kesehatan yang memadai di rumah sakit dikarenakan kekurangan biaya, untuk itu pengembangan dalam bidang kesehatan sangat membantu mereka yang membutuhkan. Pembangunan rumah sakit, poliklinik, apotik dan alat-alat medis lainnya, serta pemberdayaan dan pengembangan SDM kesehatan dari dana wakaf akan meringankan beban pemerintah dalam bidang kesehatan

3. Bidang Pelayanan Sosial

Dana wakaf terutama wakaf tunai akan membantu dalam pembangunan bidang pelayanan social untuk pembnagunan fasilitas umum yang lebih memadai, tempat- tempat ibadah atau lembaga keagamaan yang representative, lalu pemberdayaan kaum dhuafa melalui berbagai pelatihan, dan membuat berbagai proyek wadah yang mencakup beberapa bidang. 
Implementasi Pendistribusian Wakaf .... $\mid 61$

4. Bidang Pengembangan UKM

Usaha Kecil Menengah (UKM) yang berkembang akan membuat UKM mampu meningkatkan daya saing produknya dan bukan tidak mungkin akan dapat dapat menjangkau pasar luar negeri. Untuk itu perlu dilakukan hal-hal seperti memprioritaskan pembinaan dan pengembangan UKM yang menggunakan bahan baku dari sumber daya alam dan industri pendukungnya untuk pasar dalam dan luar negeri seperti agro industri, kerajinan keramik dan gerabah. Selanjutnya dalam kaitannya dengan wakaf tunai adalah memberi peluang besar kepada lembaga dan nadzir wakaf tunai untuk berartisipasi aktif dalam menyediakan fasilitas permodalan bagi UKM. Membantu pemasaran dan promosi UKM dan pembangunan infrastuktur yang mendukung pemberdayaaan ekonomi rakyat juga bisa dilakukan dengan memanfaatkan dana wakaf tunai yang ada.

Usaha mikro mempunyai peranyang sangat penting dalam pembangunan ekonomi, karena jumlah usaha mikro di Indonesia selama ini menempati lebih dari 95\% pelaku bisnis di Indonesia. Usaha mikro juga dapat beradaptasi terhadap perubahan pasar dan tahan krisis karena lebih fleksibel.

\section{Metode Penelitian}

1. Pendekatan Penelitian

Penelitian ini menggunakan pendekatn penelitian kualitatif. Dimana data yang terkumpul akan diolah dan dianalisa secara deskriptif. Penelitian kualitatif merupakan penelitian yang menekankan pada proses yaitu tidak menjadikan hasil penelitian sebagai orientasi keberhasilan suatu data melainkan kebenaran hipotesa yang disajikan melalui hasil pebelitian gejala sosial yang ada.

2. Jenis dan Sumber Data 
Sumber data merupakan hal yang paling penting di dalam prosespenelitian. Sumber data yang relevan merupakan cerminan dari integrase informasi yang ada di dalam penelitian. Pada penelitian ini, sumber data yang digunakan adalah data primer dan sekunder. Data primer merupakan sebuah informasi dan data yang diperoleh penulis secara langsung dari tempat penelitian atau objek penelitian. Data yang diperoleh merupakan hasil dari wawancara dengan pihak BWUT yang diamanahi memberikan informasi, dan dokumen tertulis, program dan agenda lembaga tempat penelitian. Data sekunder merupakan data- data yang tersedia dan dapat diperoleh oleh penulis dengan cara membaca, melihat dan mengamati. Dalam penelitian ini penulis akan memperoleh data berupa jurnal, buku dan hasil penelitian terdahulu yang berkaitan dengan penelitian.

3. Teknik Pengumpulan Data

Teknik pengumpulan data yang dilakukan di dalam penelitian ini adalah wawancara mendalam, observasi partisipan dan studi dokumentasi.Wawancara adalah proses memperoleh keterangan untuk tujuan penelitian dengan cara tanya jawab sambal bertatap muka antara pewawancara dengan informan atau orang yang diwawancarai, dengan atau tanpa menggunakan pedoman wawancara. Observasi adalah kemampuan seseorang untuk menggunakan pengamatannya melalui hasil kerja panca indra mata serta dibantu dengan panca indra lainnya. Maksud dari observasi adalah pengumpulan data yang digunakan untuk menghimpun data penelitian melalui pengamatan dan pengindraan. Metode observasi ini dilakukan secara teliti dan sistematis untuk mendapatkan hasil yang bisa diandalkan. Observas disini dengan cara terjun langsung ke tempat penelitian yaitu Badan Wakaf Uang Tunai MUI Yogyakarta. Dokumentasi adalah proses melihat kembali sumber- sumber data dari dokumen yang ada dan dapat digunakan untuk memperluas data-data yang telah ditemukan. Adapun sumber data dokumen diperoleh dari lapangan berupa 
Implementasi Pendistribusian Wakaf .... 63

buku, arsip, majalah dan penelitian terdahulu serta dokumen perusahaan atau dokumen resmi yang berhubungan dengan focus penelitian.

4. Teknis Analisis Data

Data yang diperoleh baik dari lapangan maupun studi pustaka merupakan data kualitatif yang akan dikembangkan menjadi metode deskripsi yaitu metode yang menggambarkan secara jelas mengenai topik penelitian yang diteliti dan mengambil kesimpulan tentang hasil penelitian.

\section{Hasil Dan Pembahasan}

Implementasi pendistribusian yang diwujudkan dalam pemberian pembiayaan dari Badan Wakaf Uang Tunai (BWUT) MUI DIY yang didirikan dari modal wakaf uang adalah masyarakat yang telah mengikuti pembinan mental, spiritual keimanan masing-masing peserta program.

Pembiayaan yang diberikan menggunakan akad qard hasan sehingga penerima pembiayaan akan mengembalikan sebesar pokok saja. Selama menerima pembiayaan diharuskan mengikuti pengajian rutin yang dilaksanakan sebulan sekali. Berdasarkan periode pengajian maka periode ini digunakan juga sebagai skema pengembalian pokok pinjaman selama jangka waktu periode pinjaman, atau menghadiri pengajian sekaligus membayar angsuran pembiayaannya. Implementasi penyaluran dana wakaf tunai dalam bentuk pinjaman berupa modal usaha yang diadakan oleh BWUT MUI DIY mempunyai peran yang penting dalam pengembangan usaha mikro untuk mewujudkan kesejahteraan umat.

Hal ini dibuktikan dengan adanya perubahan pada usaha yang dijalankan oleh mauquf alaihi (para penerima pinjaman) selalu mendapatkan pendampingan dalam menjalankan usaha atau dalam menekuni pekerjaannya. Model pendampingan ini secara otomatis memiliki fungsi control terhadap usaha nasabah maka jika ada masalah pendampingan 
64 Mulyono Jamal, Jarman Arroisi, Nia Puji Agustin \& Khurun'in Zahro'

segera mengetahui dan membantu memberikan solusi yang berdampak pada bertambahnya keuntungan yang diperoleh, peningkatan jumlah produksi, peningkatan kualitas produk/ jasa bertambahnya konsumen.

Pengelolaan wakaf merupakan bagian yang terpenting dari wakaf, karena fungsi atau manfaat wakaf bias dirasakan oleh mauquf alaihi bila dikelola dengan baik, professional dan produktif. Dalam UU Wakaf dan Peraturan Pemerintah bagian pengelolaan wakaf juga diatur ada UU No. 41 Tahun 2002 tentang Wakaf diatur pada Bab V yang meliputi pasal 42-46.

1. Nazhir wajib mengelola dan mengembangkan harta benda wakaf sesuai dengan tujuan, fungsi dan peruntukannya.

2. Pengelolaan dan pengembangan harta benda wakaf oleh nadzir sebagamana dimaksud dalam pasal 42 dilaksanakan sesuai dengan syariah. Pengelolaan dan pengembangan harta benda wakaf yang dimaksud dilakukan secara produktif.

3. Dalam mengelola dan mengembangkan harta benda wakaf, nadzir dilarang melakukan perubahan peruntukan harta benda wakaf kecuali atas dasar izin tertulis dari Badan Wakaf Indonesia. Izin sebagaimana yang dimaksud hanya dapat diberikan apabila harta benda wakaf ternyata tidak dapat diperhunakan sesuai dengan peruntukan yan dinyatakan dalam ikrar wakaf.

BWUT MUI DIY dalam penyaluran manfaat wakaf uang tunai hanya memprioritaskan bidang pemberdayaan pelaku usaha kecil dan menengah dengan bantuan pinjaman Protab, karena masih terbatasnya dana. Untuk program selanjutnya BWUT MUI DIY akan merambah ke penyaluran manfaat wakaf uang tunai ke sector pendidikan/ beasiswa bagi pelajar yang kurang mampu dan kesehatan bagi masyarakat, saat dana sudah mencukupi. Produktivitas usaha dari para mitra wakaf tunai BWUT semakin meningkat, hal ini ditandai dengan ketertiban para mauquf alaihi dalam mengangsur cicilan pinjaman Protab. Para mauquf alaihi mendapatkan penyuluhan strategi 
\begin{tabular}{l|l} 
Implementasi Pendistribusian Wakaf .... & 65
\end{tabular}

pengembangan bisnis dari BWI, usaha mereka terus dipantau tiap bulan, dan pertemaun dengan mitra wakaf tunai mauquf alaihi itu sekaligus dalam rangka pembayaran cicilan pinjaman Protab.

\section{Kesimpulan}

Berbeda halnya dengan zakat, infaq dan sedekah, wakaf memiliki keunikan tersendiri dalam hal prinsip, tujuan dan metode penerapannya. Wakaf, terutama wakaf tunai dapat memberi kontribusi signifikan pada pengentasan kemiskinan dengan berbagai macam program dan kegiatan pengembangan dan pemberdayaan ekonomi umat.

Pengelolaan wakaf dapat ditujukan untuk memperkuat ekonomi umat dengan memanfaatkan berbagai alternative program yang pendanaan bersumber dari wakaf sehingga memperkuat kemampuan wakaf dalam memberdayakan ekonomi umat. Oleh karena itu, potensi wakaf tunai khususnya di Indonesia yang luar biasa sebagaimana dijelaskan di atas harus menapatkan penanganan manajemen yang professional. Hal ini dapat terwujud, jika masyarakat telah memahami dasar hokum dan potensi wakaf tunai. Akhirnya. Perubahan paradigma perwakafan tradisional menjadi wakaf produktif dalam bentuk wakaf tunai merupakan kesadaran semestinya diingatkan demi terjadinya peningkatan kualitas hidup dan kebahagiaan umat Islam dunia akhirat.

\section{Daftar Pustaka}

Apriadi, M. (2010). Efektivitas Penghimpunan dan Pengelolaan Wakaf Uang pada Baitu Maal Muamalat (BMM). UIN Syarif Hidayatullah.

As-Syathibi. (n.d.). Al-Muwafaqat fii Ushul As-Syariah (Juz. 1). Beirut: Dar al-Hadits al-Kutub al-Ilmiyah.

Atabik, A. (2014). Manajemen Pengelolaan Wakaf Tunai di Indonesia. ZISWAF, 1. 
$66 \mid$ Mulyono Jamal, Jarman Arroisi, Nia Puji Agustin \& Khurun'in Zahro'

Efendi, M. U. (2014). Studi Pendayagunaan Dana Wakaf Tunai pada Badan Wakaf Uang Tunai MUI Provinsi D.I. Yogyakarta.

Fatimah, S. (2015). Implementasi Wakaf Tunai Dalam UU No 41 Tahun 2004 di Bank Muamalat Indonesia Lampung Timur. Jurnal As- Salam, 4.

Ghazaly, A. R. (2010). Figh Muamalat (Cet. 1). Kencana.

Hairunas, S. (2017). Manajemen Pendistribusian Wakaf Tunai di Badan Wakaf Uang/ Tunai Majelis Ulama Indonesia Daerah Istimewa Yogyakarta. Universitas Islam Negeri Sunan Kalijaga Yogyakarta.

Hasanah, M. E. N. dan U. (2006). Wakaf Tunai Inovasi Finansial Islam. Hazami, M. N. H. R. dan B. (2016). Peran dan Implemntasi Waqaf dalam Peningkatan Kesejahteraan Masyarakat. INFERENSI, Jurnal Penelitian Sosial Keagamaan, 10.

Nafis, C. (2009). Wakaf Uang untuk Jaminan Sosial. Jurnal Al-Awqaf, 2.

Nasution, M. E. (2007). Implementasi Wakaf di Indonesia. Paper Dipresentasikan Dalam Acara Seminar Internasional: Perkembangan Dan Kebijakan Wakaf Di Kampus UHAMKA Jakarta.

Rianto, M. N. (2012). Wakaf Uang dan Pengaruhnya terhadap Program Pengentasan Kemiskinan di Indonesia. Nur Rianto, Wakaf Uang Dan Pengaruhnya Terhadap Program Pengentasan Kemiskinan Di Indonesia, INDO, 2.

Rozalinda. (2015). Manajemen Wakaf Produktif.

Setyadi, H. (2017). Pengelolaan Pengembangan Wakaf Uang Berdasarkan Peraturan Pemerintah No. 42 Tahun 2006 Pasal 48 Pada Bank BPD DIY Syariah. IQTISHODIA: Jurnal Ekonomi Syariah, 2.

Syafiq, A. (2014). Wakaf Tunai untuk Pemberdayaan Usaha Kecil. ZISWAF, 1.

Yulma, N. L. (2016). Peran Pemberdayaan Wakaf Tunai (Studi Kasus pada BMT Amanah Ummah Surabaya). Jurnal Ekonomi Syariah Teori Dan Terapan, 3. 